\title{
遠心載荷振動実験および三次元動的解析による ロックフィルダムの地震時安全性に関する研究
}

\author{
有賀 義明 $^{1}$ ・ 曹 増延 ${ }^{2}$ - 渡邊 啓行 $^{3}$
}

】フェロー会員 博 (工) 電源開発(株) 技術開発センター（テ253-0041 神奈川県茅ヶ崎市茅ヶ崎 1-9-88)

${ }^{2} \mathrm{Ph}$. D. (株) 開発計算センターエンジニアリング事業部(广135-8451 東京都江東区深川 2-2-18)

${ }^{3}$ フエロー会員 工博 埼玉大学教授 工学部建設工学科(テ338-8576 埼玉県さいたま市下大久保 255)

非常に強い地震動を受けたロックフィルダムの地震時安全性の評価手法の高度化, 合理化を図るために,

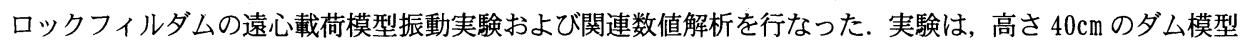
を作成し，40Gの遠心重力場において最大加速度 $40 \mathrm{G}$ までの地震動を入力加振して実施した. この実験に より, 大ひずみレベルの堤体材料の動的変形特性, 地震時挙動の三次元性, 地震時の過剩間隙水圧の挙動, 堤体の損傷過程および椇傷形態などを明らかにした. 更に, 遠心載荷模型実験の三次元シミュレーション により，強い地震動に対する堤体の動的変形特性について定量的な評価考察を加えた.

Key Words : rock-fill dam, dynamic centrifuge test, failure process, failure model, numerical simulation, nonlinear property

\section{1.はじめに}

ロックフィルダムの耐震性評価は，何ら損傷が生じ ない段階の評価と何らかの損傷が生じた後の評価とに 分けて考えることができる. 前者は “応力評価” の領 域になり, 後者は“変形評価” の領域になる. 従来, わが国では, ダム堤体の構造的な安定性の確保がダム の貯水機能保持の前提になることから, 震度法および 修正震度法に基づいて, 基本的に応力評価の領域にお ける耐震設計が行われている.

ところで, これまでの国内外のロックフィルダムの 地震遭遇事例を分析してみると, 大きな地震動に遭遇 した際に，ダムの貯水機能が損なわれるような重大な 地震被害を受けた事例は報告されていない.しかし， 地震によりダム堤体に残留変形や亀裂等が発生した事 例は幾つか報告されている ${ }^{1) \sim 22}$. こうした過去の地震 被害事例は, ロックフィルダムの耐震性評価の精度と 信頼性を高め, より合理的な評価手法を確立するため には, 非常に強い地震動を受けた際のロックフィルダ 么の動的変形特性, 損傷過程, 損傷形態等を解明し, 損傷量 (残留変形量等)を定量的に評価することが必要 であることを示唆するものである. 更には, 構造的な 損傷が発生した後のダムの貯水機能保持を合理的に確 認することが必要であることを示すものである.
また，ロックフィルダムの損傷形態に関しては, 一 般的に, 基本的な破壊形態として,すべり破壊が想定さ れているが, これまでの地震被害事例では，ロックフ イルダムが円弧すべりで破壊した事例は報告されてい ない. そして,これまでに実施されている $1 \mathrm{G}$ 場の模 型振動実験による研究でも, 粘性のある土質材で構成 されるアースフィルダムでは円弧すべり破壊が生じる が, 粘性のほぼない粗粒材で構成されるロックフィル ダムに関しては, 円弧すべりの破壊形態は生じないと する研究報告が多い ${ }^{13) \sim 18)}$. しかしながら，これまでの 地震被害事例に関しては, 過去に実ダムが遭遇した地 震動レベルが必ずしも十分に高レベルであったとは限 らず, また, $1 \mathrm{G}$ 場の模型振動実験に関しては, 重力の 影響に関する相似則が成立しないという制約があった. そのため, ロックフィルダムの損傷過程や損傷形態に 関して, 非常に強い地震動が作用した場合にはどのよ うになるのか，相似則が成立する振動実験を実施した 場合には果たしてどのような結果になるのかという点 について未解明の課題が残存していた. 更に, ロック フィルダムの動的変形特性, 通常, 室内の振動三軸試 験によって評価されるが 19) 22)，一般に，試験装置の 載荷能力の制約から, 耐震性を評価する上で最も重要 な, 大きなひずみレベルでの動的変形特性が評価でき ない場合が多く, 室内の振動三軸試験で評価した物性 
值が実際の既設ダムの動的変形特性を忠実に反映した ものであるかどうかについての実証がまだ十分にはな されていない ${ }^{23) ~ 32) . ~}$

このような必要性から, 非常に強い地震動を受けた ロックフィルダムの耐震性評価手法の高度化, 合理化 を図るために, 重力の影響に関する相似則をほぼ満足 する遠心載荷模型振動実験を行い, 既往の研究では十 分に解明されていなかった，大ひずみレベルでのロッ クフィルダムの動的変形特性, 地震時の損傷過程およ び損傷形態, 地震時の過剩間隙水圧挙動などについて 明らかにした. そして, 遠心載荷模型振動実験に関す る数值シミュレーションを行い, 強い地震動を受けた ロックフィルダムの動的変形特性について定量的な評 価考察を行った. さらに, 弾塑性有効応力解析を行い, 数值解析によりロックフィルダムで生じる過剩間隙水 圧および損傷形態を予測する可能性があるかどうかに ついても考察した.

\section{2. 遠心載荷模型振動実験によるロックフィル ダムの耐震性の検討}

\section{（1）実験目的}

非常に強い地震動に対するロックフィルダムの耐震 性を定量的に研究するために, 拘束圧に依存する強度 と剛性に関する相似則が明確である, 遠心載荷模型振 動実験を行った. 遠心載荷模型振動実験の主な目的は, 表ー1に示したとおりである.

\section{（2）実験方法}

\section{a) 夕厶模型の形状}

ダム模型の形状は, 中央コア型ロックフィルダムを 実験対象とし, 高さ $40 \mathrm{~cm}$, 天端幅 $5 \mathrm{~cm}$, 堤頂長 $90.5 \mathrm{~cm}$, 上·下流面勾配 $1: 1.8$ とした. ダム模型の中央断面の 形状は，図-1 に示すとおりである. 谷形状に関して は，図ー2 に示したように，U字形の谷とV字形の谷 の 2 種類を設定した. ダム模型の中央断面は，U字谷 模型も $\mathrm{V}$ 字谷模型も同じである. $\mathrm{V}$ 字谷部の斜面勾配 は $1: 1.13$ である.

\section{b). ダム模型の材料}

コア部は, カオリン粘土 : 硅砂 : セメント : 水を重 量比で $8: 12: 1: 10$ で混合し作製した. ロック部は, 神奈川県厚木産の砂岩・角㗭岩の砕石を実夕゙ムの代表 的な粒度分布を想定した相似粒度に配合調整(最大粒 径 $9.5 \mathrm{~mm}$ )し作製した. 想定した実ダムの粒度分布およ び模型材料の粒度分布を图一 3 に示す．V字谷模型の 谷部は, カオリン粘土 : 硅砂 : セメント : 水を重量比 で $10: 10: 10: 15$ で混合し作製した. 作製したロック 部, コア部, 谷部( $\mathrm{V}$ 字谷模型) の模型材料の主な物
表 -1 遠心載荷模型振動実験の目的

\begin{tabular}{|c|c|}
\hline & 主な研究目 的 \\
\hline \multirow{3}{*}{1} & 大ひずみレベルでの動的変形特性の評価 \\
\hline & 強い地震動を受けたロックフィルダムの動的せん断 \\
\hline & 剛性及び減衰定数の定量的評価 \\
\hline \multirow[b]{2}{*}{2} & 地震時応答特性の三次元性の検討 \\
\hline & 谷形状の相違による地震時応答特性の検討 \\
\hline \multirow{3}{*}{3} & 地震動レベルと残留変形量との関連性の検討 \\
\hline & 強い地震動を受けた場合の残留変形量と地震動レベ \\
\hline & ルとの関連性の解明 \\
\hline \multirow{3}{*}{4} & 地震時間隙水压の発生状況の把握解明 \\
\hline & 上流側堤体内部での地震時間隙水圧の発生状況, 地 \\
\hline & 震時の過剩間隙水圧発生の把握解明 \\
\hline \multirow{3}{*}{5} & 地震時の損傷過程, 損傷様式の把握解明 \\
\hline & 非常に強い地震動を受けたロックフィルダムの損賃 \\
\hline & \\
\hline
\end{tabular}

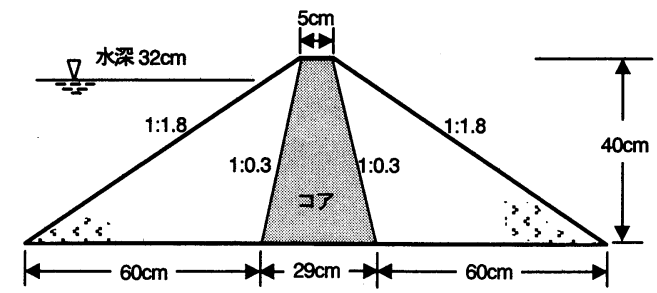

（U字谷模型， V字谷模型共通）

図-1 実験模型としたロックフィルダムの中央断面

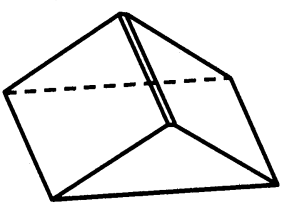

（1）U字谷模型の概形

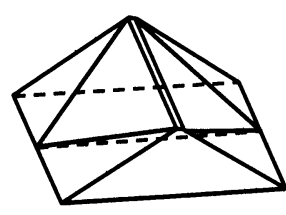

（2） V字谷模型の概形
图-2 U字谷模型とV字谷模型の概形

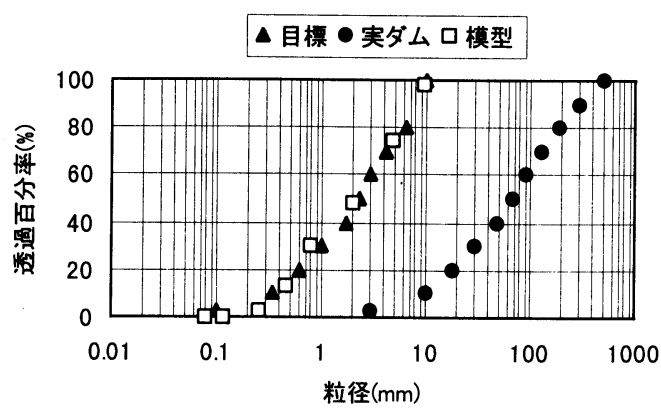

図－3 実ダムおよび模型材料の粒度分布

性值を表一2 に示す．貯水材料には，水道水を使用し， 貯水深は $32 \mathrm{~cm}$ とした. 
表-2 ダム模型の物性値

\begin{tabular}{l|c|c|c}
\hline \multicolumn{1}{c|}{ 目 } & ロック部 & コア部 & 谷 部 \\
\hline 密 度注 $\left(\mathrm{t} / \mathrm{m}^{3}\right)$ & 1.85 & 1.52 & 1.64 \\
\hline 間 隙 比 & 0.33 & - & - \\
\hline $\begin{array}{c}\text { 一軸圧縮強度 } \\
\left(\mathrm{N} / \mathrm{mm}^{2}\right)\end{array}$ & - & 0.2 & 2.0 \\
\hline 内部摩擦角 $($ 度 $)$ & 37 & - & - \\
\hline 透水係数 $(\mathrm{cm} / \mathrm{s})$ & $2.3 \times 10^{-1}$ & $5.6 \times 10^{-4}$ & \\
\hline $\mathrm{S}$ 波速度 $(\mathrm{m} / \mathrm{s})$ & 220 & 370 & 945 \\
\hline
\end{tabular}

注*:ロック部は乾燥密度, コア部と谷部は湿潤密度

表一3 遠心載荷振動実験装置の主な性能

\begin{tabular}{l|lc}
\hline \multicolumn{1}{c|}{ 装 置 } & \multicolumn{1}{c}{ 項 目 } & 性 能 \\
\hline \multirow{4}{*}{ 静的 } & 回転半径 & $9.14 \mathrm{~m}$ \\
遠心載荷装置 & 最大搭載容量 & $1092 \mathrm{tG}$ \\
& 最大遠心加速度 & $50 \mathrm{G}$ \\
& 載荷領域 & $2 \mathrm{~m} \times 1 \mathrm{~m}$ \\
\hline \multirow{4}{*}{ 動的 } & 形式 & 油圧サーボ式 \\
振動実験装置 & 最大搭載質量 & $2500 \mathrm{~kg}$ \\
& 最大加振加速度 & $40 \mathrm{G}$ \\
& 最大加振力 & $490 \mathrm{kN}$ \\
& 最大速度 & $70 \mathrm{~cm} / \mathrm{s}$ \\
& 最大変位 & $10 \mathrm{~mm}$ \\
\hline
\end{tabular}

\section{c）遠心載荷装置と計測装置}

遠心載荷振動実験には, 米国カリフォルニア大学デ 一ビス校の実験装置を使用した．使用した遠心載荷振 動実験装置の基本性能を表一3 に示す。主な性能は, 回転半径 $9.14 \mathrm{~m}$, 最大搭載容量 $1092 \mathrm{t} \mathrm{G}$, 静的な最大遠 心加速度 $50 \mathrm{G}$, 最大加振加速度 $40 \mathrm{G}$ である.

計測センサ一の配置は, U字谷模型も $\mathrm{V}$ 字谷模型も 全く同様であり，図-4 にその配置状況を示す．表－4 に実験で使用した加速度計, 変位計, 過㮃間隙水圧計 の主な性能を示す. 表面の変形, 損傷を観測するため, 毎秒 500 コマの撮影が可能な高速ビデオカメラを 7 ケ 所に設置した. このほか, 実験前後に位置を観測する ため, 模型の表面と側面でマーカとして着色砕石を水 平方向 $20 \mathrm{~cm}$ と鉛直方向 $10 \mathrm{~cm}$ メッシュで設置した.

d）相似則

遠心載荷模型振動実験に関する相似則を表ー5 に示 す. 遠心載荷振動実験では, 密度, ひずみ, 応力, 速 度, 剛性に関して, “模型 : 実物=1:1”の関係が成立 し, 深度方向に依存する物性や現象のうち, 地盤剛性 や強度の拘束圧依存性に関しては, 力学的な相似性が 成立する. したがって，模型実験で得られる応力〜ひ ずみ関係は，そのまま実物に当てはめて考えることが でき，実験結果に基づいた定量的な評価検討が可能で ある. 加速度と周波数と透水係数に関しては,「模
表-4 主な計器の仕様

\begin{tabular}{|c|c|}
\hline $\begin{array}{l}\text { 压 加 } \\
\text { 電 } \\
\text { 素 } \\
\text { 型 } \\
\text { 計 }\end{array}$ & $\begin{array}{l}\text { (1) 本体の寸法 : 検出部 } \phi=12 \mathrm{~mm}, \mathrm{~L}=15 \mathrm{~mm} \\
\text { (2) 動作環境 : }-18^{\circ} \mathrm{C} \sim 120^{\circ} \mathrm{C} \\
\text { (3) 入力レンジ : 最大 } 500 \mathrm{G} \\
\text { (4) 周波数特性 : } 1 \mathrm{~Hz} \sim 10 \mathrm{kHz} \text {, 位相特性とも } \\
\text { フラット. 計器校正を実施し, 校正係数の } \\
\text { 変動が士 } 3 \% \text { 以内. }\end{array}$ \\
\hline 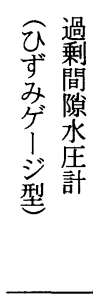 & $\begin{array}{l}\text { (1) 動作環境: }-20^{\circ} \mathrm{C} \sim+120^{\circ} \mathrm{C} \\
\text { (2) 入力レンジ : 最大 } 700 \mathrm{kPa} \\
\text { (3) 直線性 : } \pm 0.2 \% \\
\text { (4) 温度誤差 : } \pm 0.2 \% \\
\text { (5) 計器校正 : 定期的に行い, 圧力容器内に } \\
\text { センサーを㨂入して加圧し, 圧力と出力電 } \\
\text { 圧值の関係から校正係数を算出. }\end{array}$ \\
\hline $\begin{array}{l}\text { 電 変 } \\
\text { 圧 竐 } \\
\text { 抵 } \\
\text { 挨 } \\
\text { 知 } \\
\text { 型 }\end{array}$ & $\begin{array}{l}\text { (1) 本体の寸法: } \phi=15 \mathrm{~mm}, \mathrm{~L}=200 \mathrm{~mm} \\
\text { (2) 動作環境 : }-55^{\circ} \mathrm{C} \sim 125^{\circ} \mathrm{C} \\
\text { (3) 入力レンジ : 最大 } 102 \mathrm{~mm} \\
\text { (4) 直線性 : } \pm 0.15 \% \\
\text { (5) 計器校正 : 定期的に行い, ダイアル式校 } \\
\text { 正装置（測定精度 } 0.025 \mathrm{~mm} \text { ) の変位と計器 } \\
\text { 出力電圧値の関係から校正係数を算出. }\end{array}$ \\
\hline
\end{tabular}

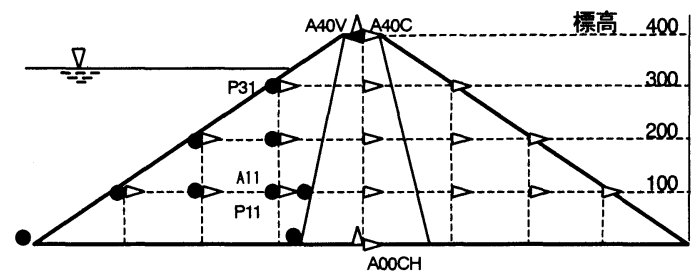

凡例：口加速度計 $、$ 変位計 - 間隙水圧計

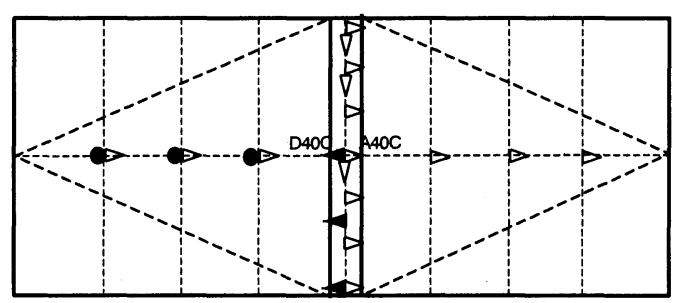

図-4 ダム模型での計器の配置

表－5 遠心載荷模型振動実験に関する相似則

\begin{tabular}{|c|c|c|c|}
\hline 項 目 & 相 似 率 & 項 目 & 相 似率 \\
\hline 遠心加速度 & $\mathrm{N}$ & 加速度 & $\mathrm{N}$ \\
\hline 幾何寸法 & $1 / N$ & 速度 & 1 \\
\hline 密度 & 1 & 変位 & $1 / \mathrm{N}$ \\
\hline 応力 & 1 & 時間 & $1 / \mathrm{N}$ \\
\hline ひずみ & 1 & 周波数 & $\mathrm{N}$ \\
\hline 剛性 & 1 & 透水係数 & $\mathrm{N}$ \\
\hline
\end{tabular}




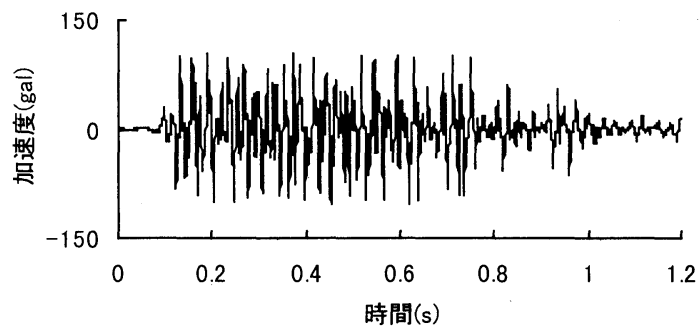

(a) 東海想定波

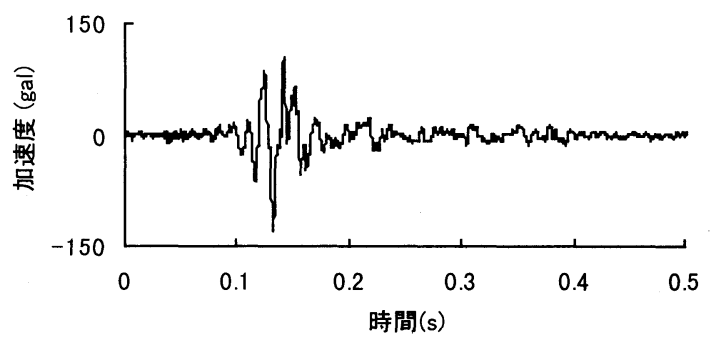

(b) 箕面川波

図ー5 振動実験に使用した入力波

型 : 実物 $=40: 1 」$ の関係が成り立ち, 時間軸に関して は「模型 : 実物 $=1: 40$ 」の関係が成り立つ.

\section{e）静的遠心力と入力波}

遠心載荷時の静的遠心加速度は $40 \mathrm{G}$ とし, $40 \mathrm{G}$ の遠 心力場で実験を実施した. 入力波は, ホワイトノイズ, サイン波, 東海地震を想定して作成した模擬地震動(以 下「東海想定波」と記す), 兵庫県南部地震の際に箕面川 ダムで観測された地震動(以下「箕面川波」と記す) を使 用した. 実験に使用した, 東海想定波および箕面川波を, それぞれ図ー5(a) と図ー5(b)に示す. サイン波の振動 数については, 加振レベルが $30 \mathrm{G}$ 以上の場合, 模型の 固有振動数が約 $50 \mathrm{~Hz}$ に低下することを勘案して, 加振 波の振動数を $50 \mathrm{~Hz}$ と設定した.

\section{f）加振方法と実験ヶース}

地震波の入力加振は, まず予備実験として, 最大加 速度 $1 \mathrm{G}$ の正弦波スイープ, 0.5Gのホワイトノイズ, $5 \mathrm{G}$ の正弦波 $(50 \mathrm{~Hz})$ による加振を行った. その後, 貯水 無しの状態で, ダム模型底面での目標最大加速度を 10 Gに設定して “箕面川波 $\rightarrow$ 東海想定波 $\rightarrow$ 正弦波 $(50 \mathrm{~Hz})$ ” の順で入力加振した. この加振順序は, ダムに発生す る応力や変形挙動に対する各入力波の影響度を勘案し て決めた. そして, 本実験として, 貯水有りの状態で, 目標最大加速度を $10 \mathrm{G}, 20 \mathrm{G}, 30 \mathrm{G}, 40 \mathrm{G}$ の 4 段階に 設定して入力加振した. 各実験ケースの実験条件は, 表一6に示すとおりである.

\section{（3）実験結果}

$\mathrm{U}$ 字谷模型 1 体とV字谷模型 1 体の合計 2 体による
表-6 遠心載荷模型振動実験ケース

\begin{tabular}{|c|c|c|c|c|c|}
\hline \multirow{2}{*}{$\begin{array}{l}\text { 順 } \\
\text { 度 }\end{array}$} & \multicolumn{2}{|c|}{ 実験ケース名 } & \multirow{2}{*}{$\begin{array}{l}\text { 貯 } \\
\text { 水 }\end{array}$} & \multicolumn{2}{|c|}{ 入力加速度波 } \\
\hline & U字谷 & V字谷 & & 目標 & 波 形 \\
\hline 1 & UD. R. 01 & VD. R. 01 & 無 & $1 \mathrm{G}$ & 正弦波久1-7 \\
\hline 2 & UD. W. B1 & VD. W. B1 & \begin{tabular}{c|c|} 
無 \\
\end{tabular} & $0.5 \mathrm{G}$ & 机仆伿 \\
\hline 3 & UD. S. 02 & VD. S. 04 & 無 & $5 \mathrm{G}$ & 正弦波 (50Hz) \\
\hline 4 & UD. M. 08 & VD. M. 13 & $\begin{array}{ll}\text { 無 } \\
\end{array}$ & $10 \mathrm{G}$ & 箕面川波 \\
\hline 5 & UD. T. 06 & VD. T. 11 & 無 & $10 \mathrm{G}$ & 東海想定波 \\
\hline 6 & UD. S. 12 & VD. S. 10 & 無 & $10 \mathrm{G}$ & 正弦波 $(50 \mathrm{~Hz})$ \\
\hline 7 & UW. R. 01 & VW. R. 01 & 有 & $\overline{1 G}$ & 正弦波久1-70 \\
\hline 8 & UW. W. B3 & VW. W. B2 & 有 & $0.5 \mathrm{G}$ & 㕲仆保 \\
\hline 9 & UW. S. 04 & VW. S. 03 & 有 & $5 \mathrm{G}$ & 正弦波 (50Hz) \\
\hline 10 & UW. M. 10 & VW. M. 11 & 有 & $10 \mathrm{G}$ & 箕面川波 \\
\hline 11 & UW.T. 10 & VW. T. 11 & 有 & $10 \mathrm{G}$ & 東海想定波 \\
\hline 12 & UW. S. 11 & VW. S. 10 & 有 & $10 \mathrm{G}$ & 正弦波 $(50 \mathrm{~Hz})$ \\
\hline 13 & UW. M. 20 & VW. M. 23 & 有 & $20 \mathrm{G}$ & 箕面川波 \\
\hline 14 & UW. M. 30 & VW. T. 20 & 有 & $20 \mathrm{G}$ & 箕面川/東海 \\
\hline 15 & UW.T. 17 & VW. S. 24 & 有 & $20 \mathrm{G}$ & 東海/正弦波 \\
\hline 16 & UW. S. 23 & VW.M. 32 & 有 & $30 \mathrm{G}$ & 正弦波/箕面川 \\
\hline 17 & UW. T. 24 & VW.T. 28 & 有 & $30 \mathrm{G}$ & 東海想定波 \\
\hline 18 & UW. S. 30 & VW. S. 32 & 有 & $30 \mathrm{G}$ & 正弦波 $(50 \mathrm{~Hz})$ \\
\hline 19 & UW. M. 33 & VW. M. 36 & 有 & $40 \mathrm{G}$ & 箕面川波 \\
\hline 20 & UW. T. 32 & VW.T. 36 & 有 & $40 \mathrm{G}$ & 東海想定波 \\
\hline 21 & UW. S. 34 & VW. S. 36 & 有 & $40 \mathrm{G}$ & 正弦波 (50Hz) \\
\hline 22 & UW. W. A & VW. W.A & 有 & $0.5 \mathrm{G}$ & 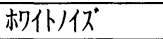 \\
\hline
\end{tabular}

【備 考】

実験个-又名：「谷形状 $\times$ 貯水有無 $\times$ 波形 $\times$ 最大加速度」

/谷形状: $U=U$ 字谷模型, $V=V$ 字谷模型

/貯水の有無: $\mathrm{D}=$ 貯水なし, $\mathrm{W}=$ 貯水あり

/波形: $\mathrm{W}=$ 㕲仆 $/$ 亿, $\mathrm{S}=$ 正弦波, $\mathrm{M}=$ 箕面川波, $\mathrm{T}=$ 東海想定波

/最大加速度: 数字=最大值, $B=$ 加振前, $A=$ 加振後

\section{実験結果を以下に示す。}

\section{a) 固有振動数}

$\mathrm{U}$ 字谷模型に関して, ダム模型の伝達関数 (天端/底 面)の卓越周波数より評価することができた, 固有振動 数とダム模型底面での入力加速度レベルとの関係を図 -6に示す. 図中, 貯水なしの場合を白抜きで, 貯水あり の場合を黒狳りで示したが,貯水の影響として,貯水に より固有振動数が若干低くなる傾向が認められた. 40 Gの遠心力場における, 入力波の最大加速度 $10 \mathrm{G}, 20$ G, 30Gは, 通常の $1 \mathrm{G}$ 重力場では, それぞれ 250gal, 500gal, 750gal に相当するが, こうした入力加速度レ ベルに対して固有振動数は大きく変化した. 同様に, $\mathrm{V}$ 字谷模型に関して評価した, 固有振動数と入力加速 度レベルとの関係を図ー7 に示す. 固有振動数と入力 加速度の関係については比較的バラツキは少なく, 非 線形性の現われ方はV字谷模型よりもU字谷模型の方 が顕著であった.ここに示した固有振動数は天端中央 (コア部) の伝達関数より求めたが, 同じ標高のコア部 とロック部の加速度時刻歴の周波数特性はほぼ同等で あり,コア部とロック部の挙動はほぼ同様であったと 考えられる. 


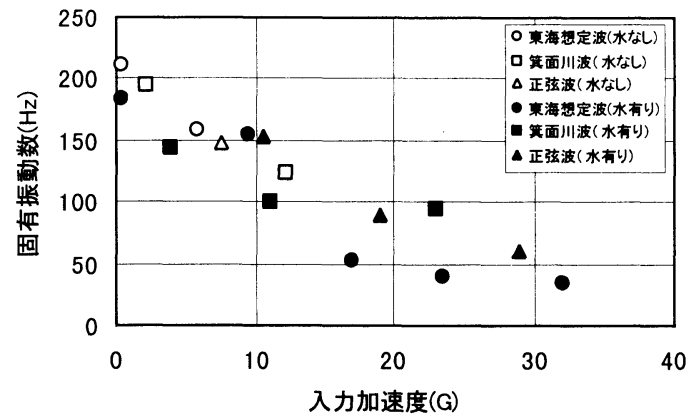

図-6 U字谷模型の固有振動数と入力加速度レベル

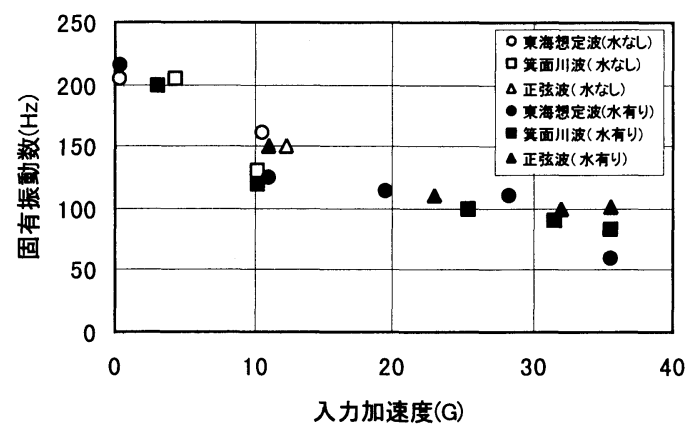

図-7 V字谷模型の固有振動数と入力加速度レベル

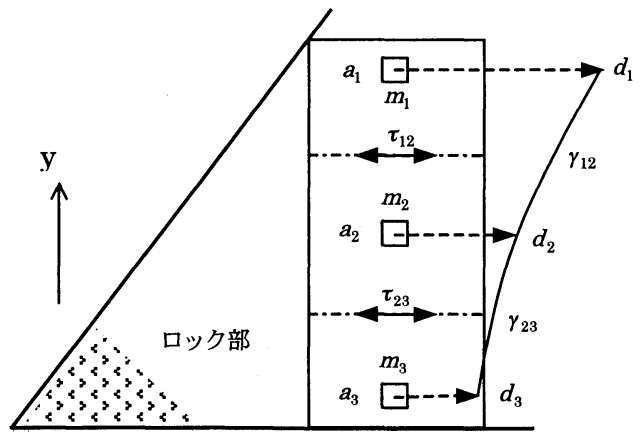

図-8 計測結果に基づく応力ーひずみ関係の求め方

\section{b）大きなひずみレベルでの動的変形特性}

振動数 $50 \mathrm{~Hz}$ のサイン波を段階的に振幅を調整して 入力加振した時の, 加速度時刻歴と変位時刻歴に基づ いてロック部の動的せん断応力と動的せん断ひずみと の関係 ${ }^{33)}$ を求めた. 実験対象は成層地盤ではないが, 図ー8に示すように，計算上, 計測センサーを中心とし たブロックの質量を評価した．計測された加速度と変 位はこれらのブロックの平均値と見なす．ブロックの 質量 $m_{i}$ と加速度 $a_{i}$ を乗じることにより各ブロックの 慣性力を求め, 次第に層内せん断応力 $\tau_{i j}$ を算定した. そして計測された変位の差分と離間距離の関倸から当 該区間のせん断ひずみ $\gamma_{i j}$ を算定した. 一般的に表すと, 式(1)の関係が成立つ.

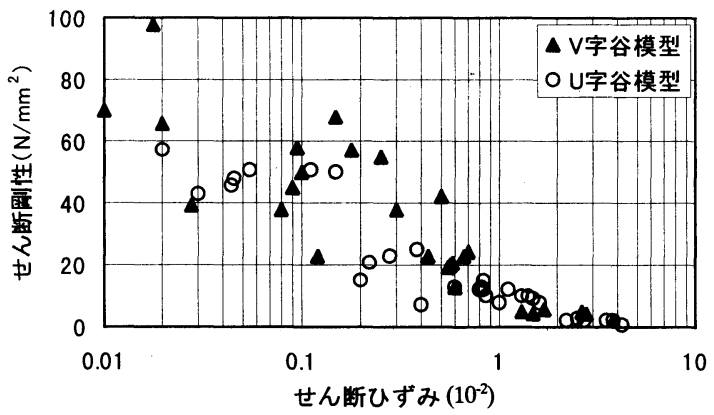

図ー9 実験から評価したロック部の動的せん断剛性

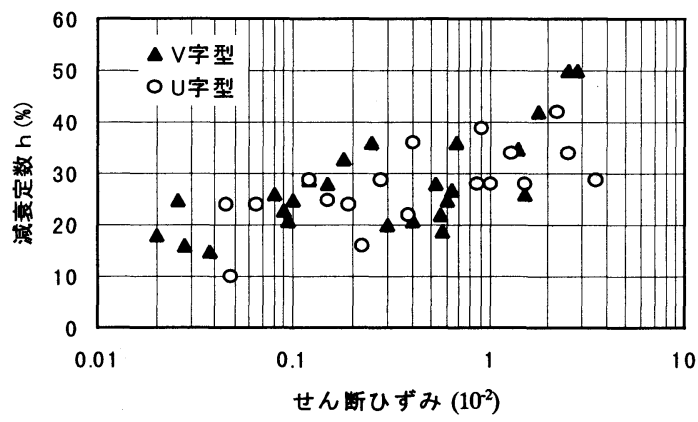

図ー10 実験から評価したロック部の減衰定数

$$
\begin{aligned}
& \gamma_{i j}=\left(d_{i}-d_{j}\right) /\left(y_{i}-y_{j}\right) \\
& \tau_{i j}=\tau_{i}+a_{j} \cdot m_{j}
\end{aligned}
$$

式(1)により得られた応力ーひずみ関係から, 等価線 形化法に基づき等価せん断剛性係数 $G$ と等価減衰定 数 $h$ を算出した.

この応力〜ひずみ関係から評価した動的せん断剛性 の結果を図ー9に, 減衰定数の結果を図一10 に示す.

概ね $5 \times 10^{-2}$ までのひずみレベルに対する動的変形特 性の結果が得られた. 減衰定数については, バラツキが 大きいが, $2 \times 10^{-4}$ から $3 \times 10^{-2}$ までのひずみレベルに 対する数値は概ね $15 \sim 47 \%$ であった.

\section{c）地震時応答の三次元性（谷形状の影笠）}

谷形状の違いによる地震時応答の比較例として, $\mathrm{U}$ 字谷模型の天端中央の加速度時刻歴を図-11に, V字 谷模型の天端中央の加速度時刻歴を図-12 に示す．天 端中央の加速度応答について, U字谷模型とV字谷模 型の実験結果を比較すると，U字谷模型では，模型底 面で東海想定波を最大加速度 $23.7 \mathrm{G}$ で入力した時の天 端での最大加速度が $81.7 \mathrm{G}$, 応答倍率は約 3.4 であっ たのに対して, V字谷模型では, 模型底面で最大加速 度 $28.4 \mathrm{G}$ で入力した時の天端の最大加速度は $51.3 \mathrm{G}$, 応答倍率は約 1.8 であった. 加振レベルが大きくなる につれて, 加速度応答は, V字谷模型よりもU字谷模 


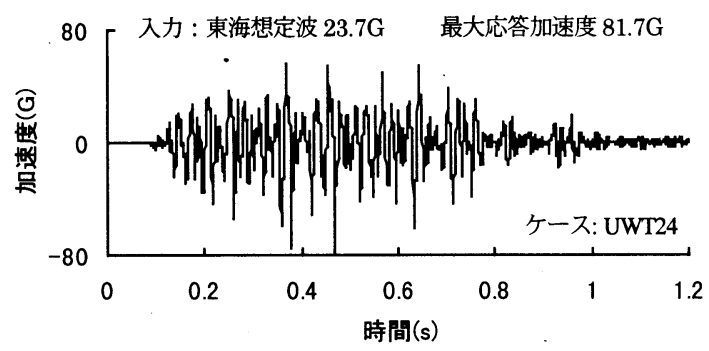

图-11 U字谷模型の天端中央の加速度時刻歴

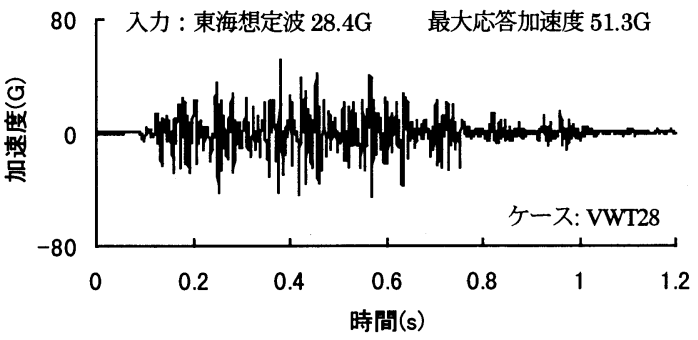

图-12 V字谷模型の天端中央の加速度時刻歷

型の方が大きくなった.これは，V字谷模型の谷部の 剛性が大きく, 谷部の固有振動数が加振波の卓越振動 数から離れているため, 谷部での地震動の増幅が小さ く, その分, ダム部での増幅が小さくなったと推定さ れる. ちなみに，ダム模型の初期の $\mathrm{S}$ 波速度は，谷部 $945 \mathrm{~m} / \mathrm{s}$, コア部 $370 \mathrm{~m} / \mathrm{s}$ ，ロック部 $220 \mathrm{~m} / \mathrm{s}$ である.

d）タム模型の残留変形と地震動レベル

U字谷模型およびV字谷模型の天端ロック部での累 積残留変形を図ー13 および図ー14 に示す. 横軸の数字 は，実験ケース番号である. 水平方向の変形は下流方 向を正，鈶直方向の変形は下方を正としている. ただ し, U字谷模型では 13 段階目以降, V字谷模型では 12 段階目以降, 加振時にコア頂部が損傷し変位計測自体 が不可能となったため, 図ー13 および図ー14にはそれ 以前の段階までの記録を掲載している.

\section{e ）強い地震動を受けた際の損傷形態}

目標最大加速度 $40 \mathrm{G}$ までの加振を行った後の, U字 谷模型の最終残留変形の状況を図ー15に, 同様に, V 字谷模型の最終残留変形の状況を図-16 示す. 目標最 大加速度 $40 \mathrm{G}$ は，実ダムでは $1 \mathrm{G}$ の最大加速度に相当 するが，大規模な破壊が一気に進行するような現象, いわゆる円弧すべり破壊が発生することはなかった. 図ー15 および図ー16 に示した残留変形の最終形状は, 振動を受けてダム模型の全域で塑性変形が発生した結 果と見られるが, 高速撮影から判定した変形は, 頂部口 ック材の剥離離脱による転がり落下であった．まず, 振動を受けて緩み, その後, 加振レベルが大きくなる

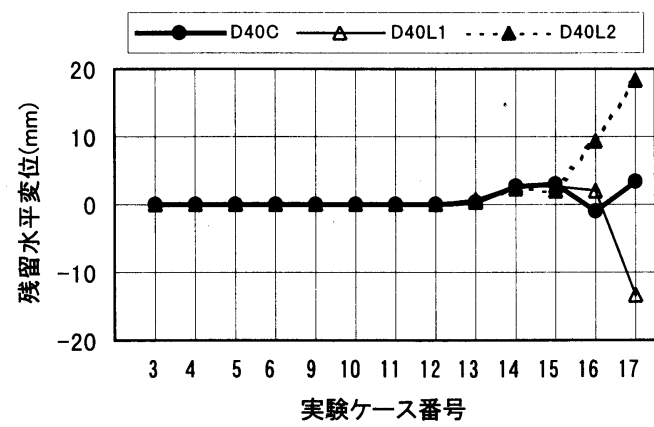

（a）累積残留水平変形量

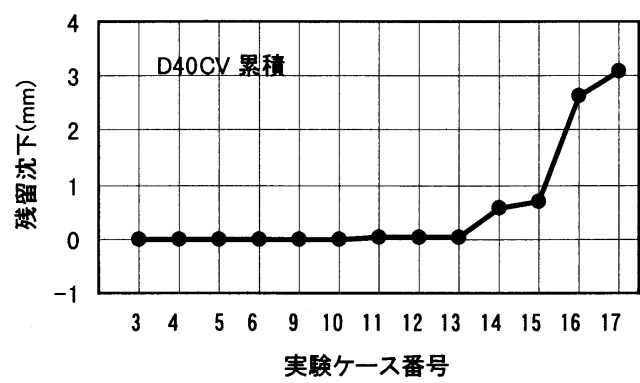

（b）累積残留鈶直変形量

図ー13 U字谷模型天端での残留変形の出現過程

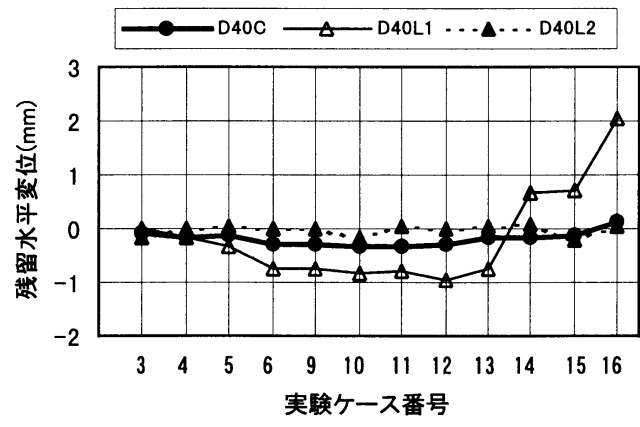

（a）累積残留水平変形量

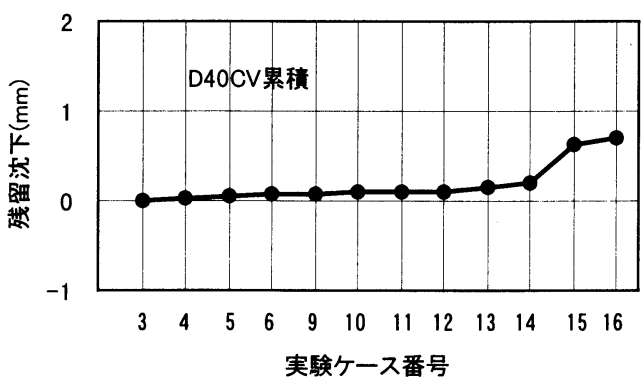

（b）累積残留鈶直変形量

図-14 V字谷模型天端での残留変形の出現過程 


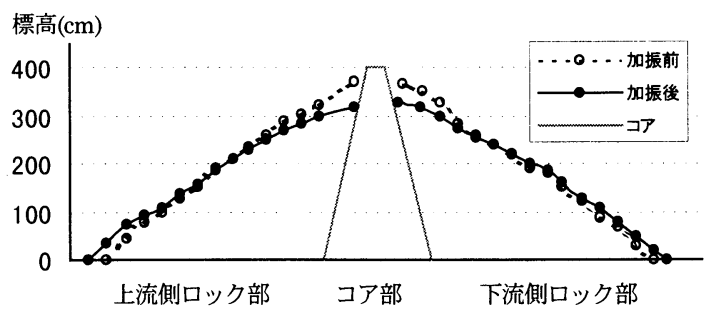

图-15 U字谷模型中央断面の残留変形の最終形状

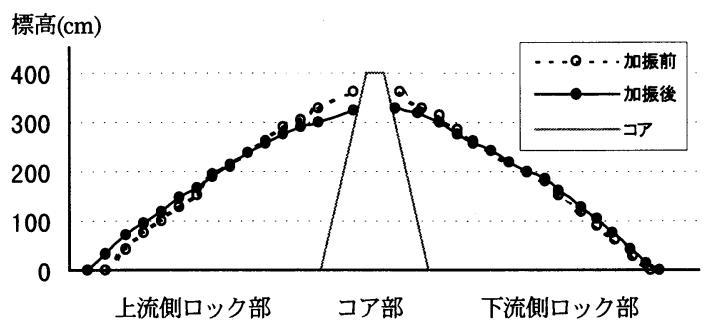

图-16 V 字谷模型中央断面の残留変形の最終形状

につれて上方のロック材が下方に転落移動した. また, 実験終了後の模型解体および観察では, 加速度計の位 置の変化は極めて少なく, ロック部の内部の変形は少 ないと推定された.

\section{f）地震時の間隙水圧}

図一4 に示した,間隙水圧計によって湛水時の上流口 ック部の間隙水圧を記録した. 例として, 目標最大加 速度 $40 \mathrm{G}$ の箕面川波および東海想定波を入力加振し た際の, U字谷模型の上流側ロック部の代表点 2 ヶ所

（表層部 P31 点と深層部 P11 点）での過剩間隙水圧の 時刻歴を図一17 と図-18 に示す. これらの間隙水圧の 正の残留分が過剩成分であり，有効応力の減少につな がる. 加振終了後, ロック部の表層部では, 過剩間隙 水圧の残留はほとんど見られないが，ロック部の深首 部では残留分が観測された．本実験では貯水に水を使 用したため, 過剩間隙水圧について定量的な評価をす ることは難しいが，実験で観察された過剩間隙水圧の 残留分の大きさは, 最大でも初期有効応力の約 $10 \%$ 程 度であった. なお，図-19 に深層部計測点の加速度応 答および間隙水圧のフーリエスペクトルを示す．両者 の主要動成分である $45 \mathrm{~Hz}$ 付近では,ほぼ同様なスぺ クトルが現れており，この分の間隙水圧は弾性体積変 形による水圧の変化であると推定される. 一方, $85 \mathrm{~Hz}$ 付近では, 間隙水圧の応答のみがやや卓越しており, この範囲の振動成分は過剩間隙水圧の発生, 上昇に対 して主に寄与していると考えられる.
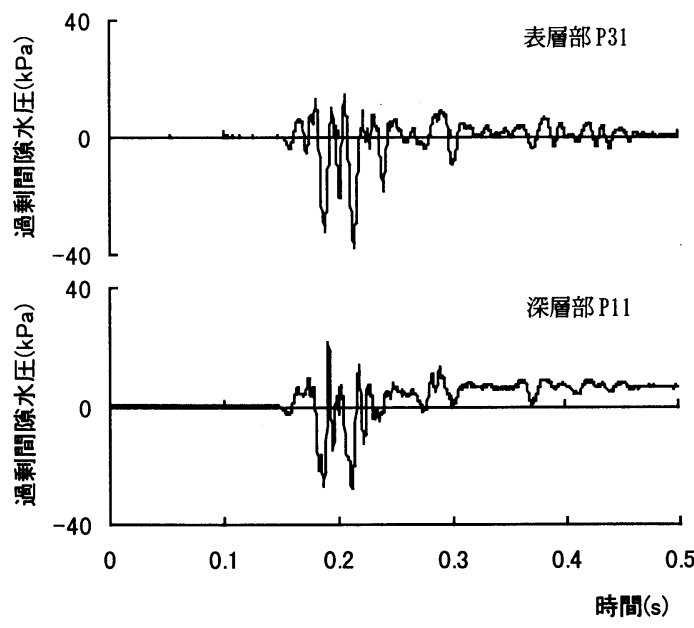

図-17 箕面川波加振時の間隙水圧時刻歴（U字谷模型）
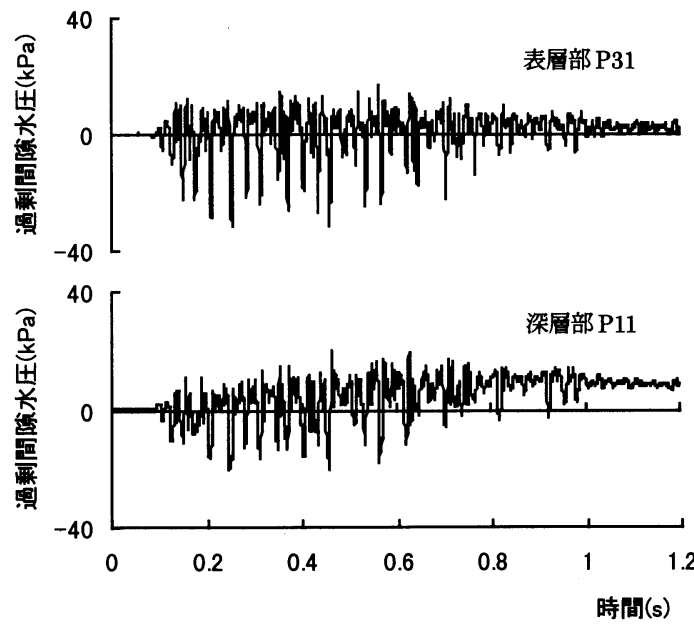

図-18 東海想定波加振時の間隙水圧時刻歴（U字谷模型）
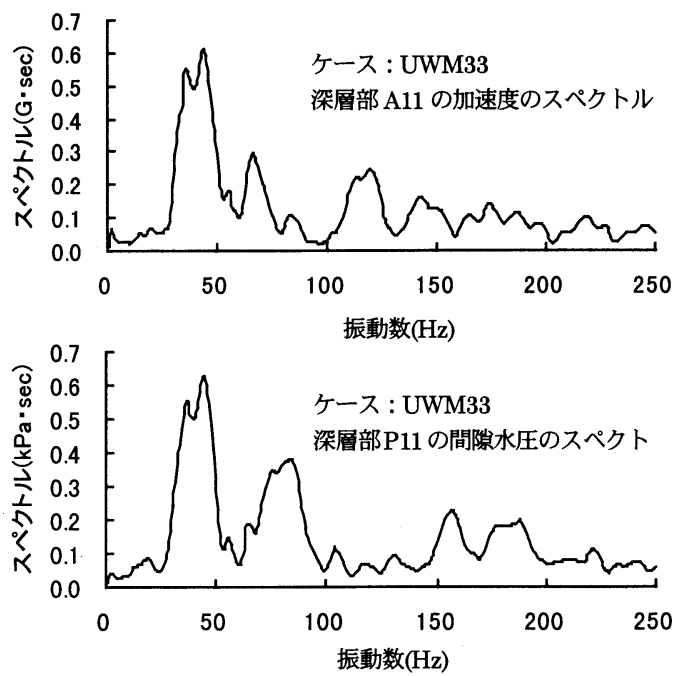

図-19 加速度と間隙水圧のスペクトルの比較 


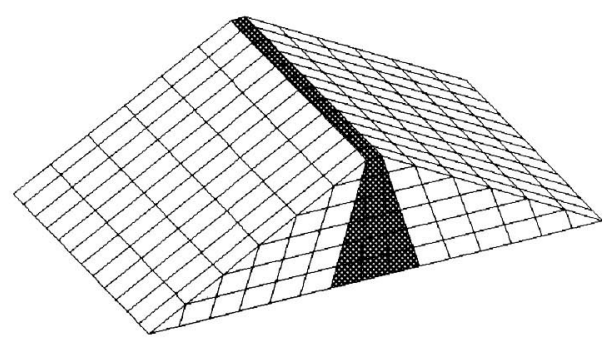

図-20U字谷模型の三次元再現解析モデル

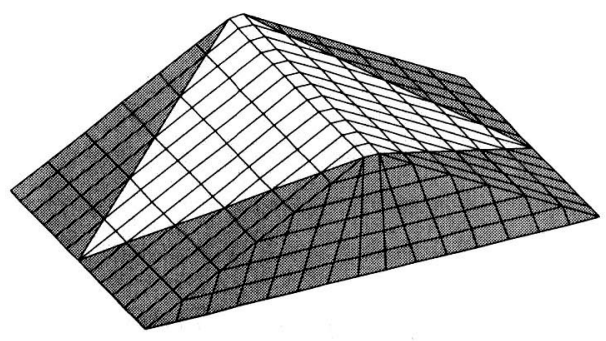

図-21 V字谷模型の三次元再現解析モデル

表-7 三次元再現解析における初期物性値

\begin{tabular}{|l|c|c|c|c|}
\hline ソーン & $\begin{array}{c}G_{0} \\
\left(\mathrm{~N} / \mathrm{mm}^{2}\right)\end{array}$ & $\begin{array}{c}\text { 密 度 } \\
\left(\mathrm{g} / \mathrm{cm}^{3}\right)\end{array}$ & $\nu$ & $\begin{array}{c}\text { 減衰定数 } \\
h(\%)\end{array}$ \\
\hline 上流吹部 & 60.0 & 2.10 & 0.33 & 0.15 \\
\hline$コ ア$ 部 & 225.5 & 1.52 & 0.17 & 0.05 \\
\hline 下流㕫部 & 60.0 & 1.84 & 0.33 & 0.15 \\
\hline 谷 部 & 1465.5 & 1.64 & 0.17 & 0.05 \\
\hline
\end{tabular}

【備考】 $G_{0}$ : 初期動的せん断岡性, $ン:$ ポアソン比

\section{3. 三次元動的解析による遠心載荷振動実験の 再現解析}

\section{(1) 解析目的}

数值解析による遠心載荷模型振動実験の再現性を検 証するために, ダム一貯水池連成系の三次元解析モデ ルを作成し，筆者らが開発した時間領域の非線形解析 プログラム “UNIVERSE” ${ }^{34) ~ 399}$ を用いて,等価線形解析 により三次元再現解析を行った. これにより,遠心載荷 模型振動実験により得られた堤体材料の動的変形特性 および非破壊段階の堤体の地震応答を確認した.

\section{（2）解析方法}

実験条件に合わせて,U字谷模型およびV字谷模型 の三次元動的解析モデル（図ー20 と図ー21に示す）を 作成し，境界条件は，下方,側方境界ともに固定境界と した，解析用物性值は，実験により評価した值（ロッ ク部の物性は図ー9 と図ー10 に示す）を用い，等価線

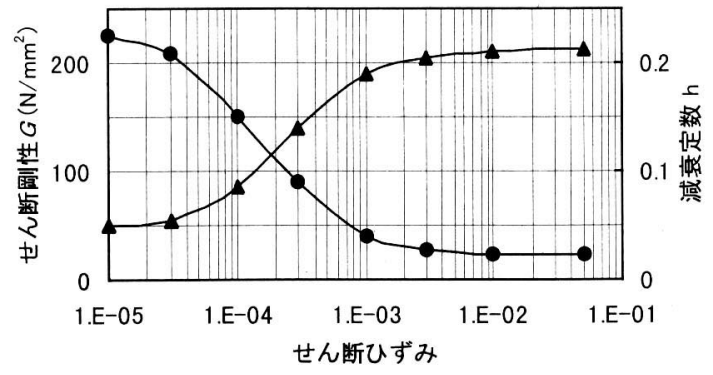

図－22 コア部の動的変形特性の非線形性

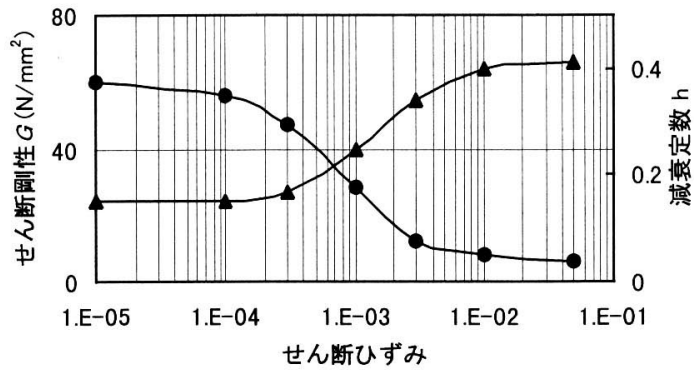

図-23 ロック部の動的変形特性の非線形性

形化法に基づき物性值を設定した. 初期物性について は, 拘束圧の依存性を考慮しながら, 平均值として表 -7 に示す值を設定した. コア部およびロック部の物 性のひずみ依存性は, 遠心載荷振動実験の結果に基づ き, 図一22 と図ー23 に示すように設定した. 加振レべ ル $20 \mathrm{G}$ (目標値) までのU字谷模型とV字谷模型のそ れぞれ 4ケース（表-8 参照）を再現対象とし, 入力 波としては, 遠心載荷実験におけるダム底面の加速度 時刻歴をそのまま使用した。

\section{(3) 解析結果}

ダム模型底部に対するダム模型天端の加速度応答倍 率に関して, 実験結果と解析結果の比較を表一8に示す. また,「U字谷模型, 貯水有」の実験ケースに関する, ダム天端の加速度時刻歷の再現解析結果を図ー24に示 す. 同様に,「V字谷模型, 貯水有」に関する,再現解 析結果を図ー25に示す. 図ー24 と図ー25より明らかな ように, 解析結果と実験結果は非常に良く一致し, 良い 再現性が得られた. 貯水有の実験に関しては, U字谷, V字谷モデル共に下流側に比して上流側の応答が若干 大きい傾向がある.これは貯水と堤体の相互作用の影 響および間隙水圧の影響と考えられる. 加速度応答倍 率に関しては, 箕面川波の場合よりも東海想定波の方 が応答倍率が大きい.これは, 東海想定波の卓越振動数 （実験では 120 200 Hz）の方が, 箕面川波（実験で は 60〜80 Hz） よりもダム模型の固有振動数（図-6 と 


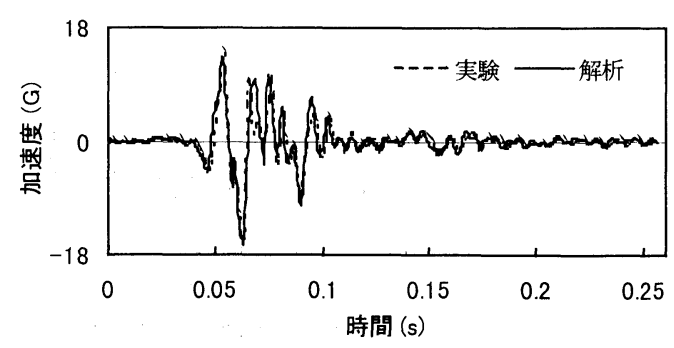

（a）Case-3[U字谷，貯水有，箕面川波 10G]

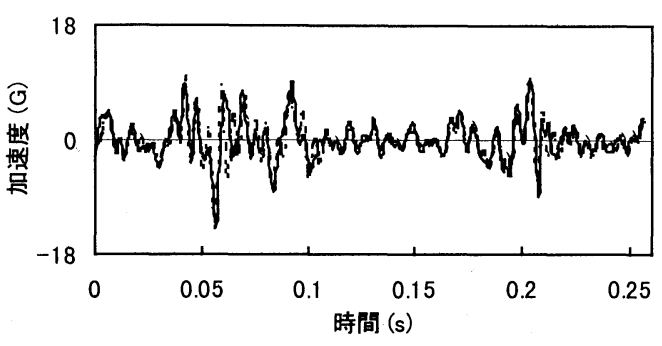

（b） Case-4[U字谷，貯水有，東海想定波 $10 \mathrm{G}$ ]

图－24U字谷模型の天端における加速度時刻歴に関する 遠心載荷振動実験結果と三次元解析結果の比較

表-8 ダム底部に対するダム天端の加速度応答倍率に 関する実験結果と解析結果の比較

\begin{tabular}{|c|c|c|c|c|}
\hline 解析竹-久 & 実験个-ス & 谷形状 & 実験 & 解析 \\
\hline Case-1 & UD. M. 08 & U字谷 & 1.55 & 1.53 \\
\hline Case-2 & UD. T. 06 & U字谷 & 2.12 & 1.84 \\
\hline Case-3 & UW.M. 10 & U字谷 & 1.50 & 1.57 \\
\hline Case-4 & UW. T. 10 & U字谷 & 2.02 & 2.09 \\
\hline Case-5 & VD. M. 13 & V字谷 & 1.45 & 1.42 \\
\hline Case-6 & VD. T. 11 & V字谷 & 1.98 & 1.67 \\
\hline Case-7 & VW.M. 11 & V字谷 & 1.59 & 1.46 \\
\hline Case-8 & VW. T. 11 & V 字谷 & 1.64 & 1.64 \\
\hline
\end{tabular}

$\mathrm{D}$ :貯水無, W:貯水有, $\mathrm{T}$ : 東海想定波, M:箕面川波

図ー7参照）に近かったためと考えられる．U字谷モ デルとV字谷モデルの比較においては，U字谷モデル

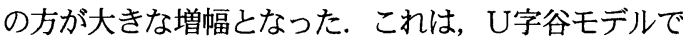
は,ダム模型底部から入力された地震波が天端に伝播 する際に増幅したのに対して, $\mathrm{V}$ 字谷モデルでは, 谷部 が堅硬であったために谷部での増幅が小さくなり，堤 体における増幅区間も短縮されたことによる結果と考 えられる.

\section{4. 三次元動的解析によるエネルギ一逸散に関する 比較検討}

剛土槽を用いた模型実験では，側方へのエネルギー の逸散はほとんどないと考えられる．したがって，再

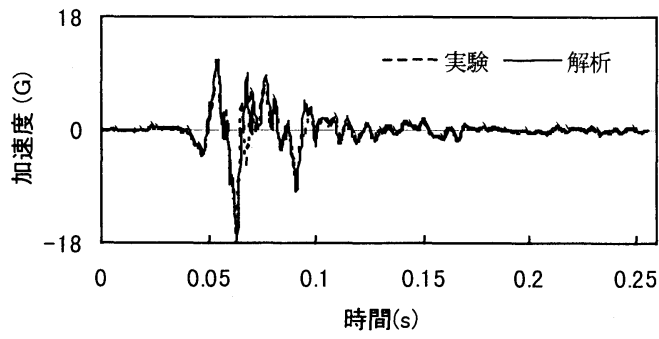

(a) Case-7[V字谷，貯水有，箕面川波 $10 \mathrm{G}$ ]

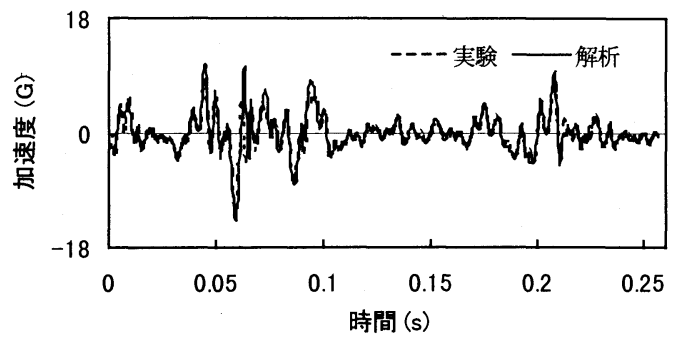

（b）Case-8[V字谷，貯水有，東海想定波 10G]

図-25 V字谷模型の天端における加速度時刻歴に関する 遠心載荷振動実験結果と三次元解析結果の比較

現解析では，基礎岩盤の境界条件は, 側方境界および下 方境界ともに剛基盤(固定境界)を設定するのが妥当と 考えられ，この解析条件で実施した再現解析は，実験 結果と非常に良い対応を示した。一方，実際のダムで は, 周辺地山へのエネルギーの逸散があると考えられ, 遠心載荷振動実験の結果を単に相似則に従って実ダム へ換算した場合，模型の固定境界条件と実ダムのエネ ルギ一逸散境界条件の違いによる誤差が生じる. そこ で, ダム模型の境界条件による影響を評価するために, 三次元再現解析モデルの境界に粘性境界を設定した比 較解析を行った. 今回の実験では, 上下流方向加振であ ったため，堤体の上下方向の挙動が比較的小さいと判 断され，解析では模型底面を剛基盤，側方境界を粘性 境界と設定した. 設定した粘性境界条件は仮想仕事原 理に基づくものである ${ }^{40)}$. 解析に用いたダム堤体モデ ルの物性は, 前出の表一7, 図一22, 図一23 に示したも のと同様であり，側方の基礎地盤の物性については, 堤体と同值であると仮定した。

逸散減衰の影響を評価する手法として，境界条件の 違いによる堤体の応答の変化に着目した. そして,粘性 境界とした場合の堤体の加速度応答が，固定境界とし た場合と一致するようにダム模型の内部減衰定数を調 整し，粘性境界による影響が内部減衰としてどれくら いに相当するかを検討した。

側方境界を粘性境界とした場合と固定境界とした場 合の加速度応答が一致するように, 減衰定数を調整し 


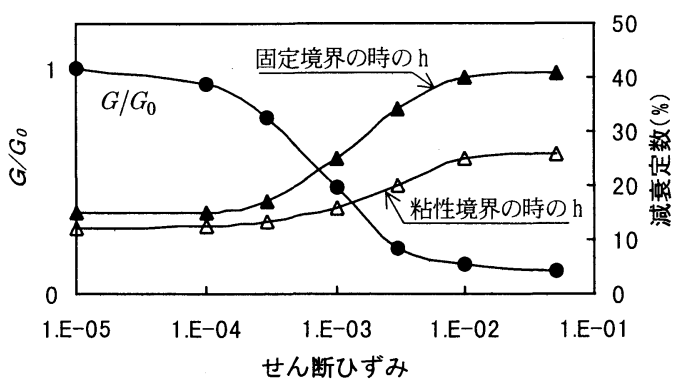

(a) ロックゾーン

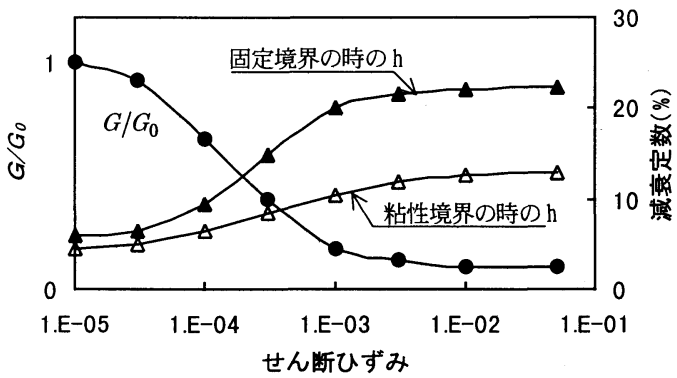

(b) コアゾーン

図-26 側方の境界条件に応じたU字谷モデルの 等価せん断剛性比と減衰定数

た結果を, 図ー26 と図ー27 に示す. 粘性境界を設定し た場合の減衰定数は, 固定境界を設定した場合に比し て, U字谷模型では最大 $15 \%, V$ 字谷模型では最大 $9 \%$ 小さくなった. この差は, 模型実験の結果に基づいて 実ダムの挙動を評価しようとするとき考慮すべき数值 であると考えられる.

\section{5. 弾塑性有効応力解析による過唾間隙水圧 および残留変形の検討}

\section{（1）解析条件}

遠心載荷振動実験でダム模型に発生した過剩間隙水 圧が, どの程度, ダムの地震応答を影響したか，また， 残留変形の形状をどの程度模擬的に再現できるかどう かを検討するために，二次元プログラム“FLAC”を用 いて弾塑性有効応力解析を試みに行った. 解析は, U 字谷模型の中央断面を対象とし, 差分法により離散化 した二次元解析モデルを作成して行なった. FLAC では, 弾塑性解析に関してはMohr-Coulomb モデルが, 地震時 の過剩間隙水圧の解析に関しては Finn モデルが用い られており, 解析で仮定した物性值は表ー9に示すと おりである.解析モデルのゾーニングは図ー28 に示す とおりである. 箕面川波（目標最大加振加速度 $30 \mathrm{G}$ ) で加振したケースを解析対象とし, 地震時の間隙水圧 応答およひ残留形態に着目して解析を行った.

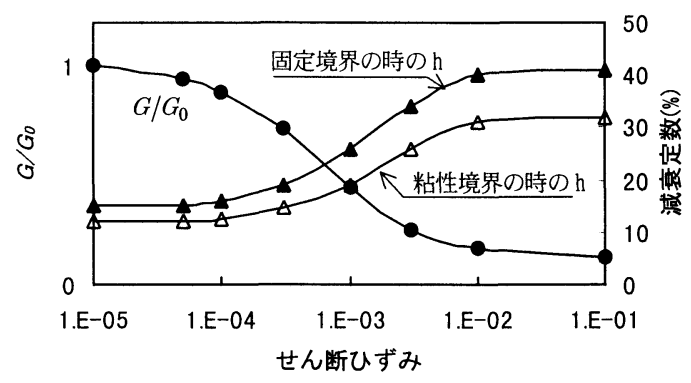

(a) ロックゾーン

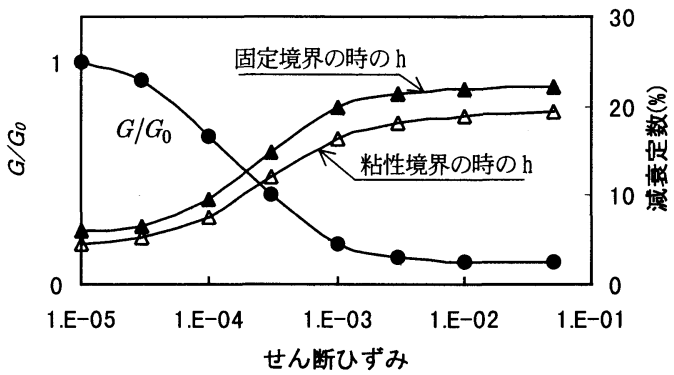

(b) コアソ゚ーン

図-27側方の境界条件に応じたV字谷モデルの 等価せん断剛性比と減衰定数

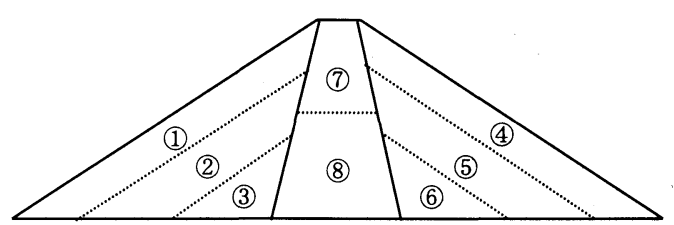

図-28 二次元弾塑性解析モデルにおける物性分布

表-9 二次元弾塑性解析で仮定した解析用物性値

\begin{tabular}{|c|c|c|c|c|c|}
\hline \multirow[b]{2}{*}{ 項 目 } & \multicolumn{5}{|c|}{ ゾーンニング } \\
\hline & (1)(4) & (2)(5) & (3) 6 & (7) & (8) \\
\hline $\begin{array}{l}\text { セ断弾性係数 } \\
\left(\mathrm{N} / \mathrm{mm}^{2}\right)\end{array}$ & 50 & 60 & 70 & 200 & 220 \\
\hline $\begin{array}{l}\text { 体積弾性係数 } \\
\left(\mathrm{N} / \mathrm{mm}^{2}\right)\end{array}$ & 150 & 180 & 210 & 330 & 370 \\
\hline 密度 $\left(\mathrm{g} / \mathrm{cm}^{3}\right)$ & 1.7 & 1.8 & 1.9 & 1.52 & 1.52 \\
\hline 粘着力 $\left(\mathrm{N} / \mathrm{mm}^{2}\right)$ & 0.08 & 0.08 & 0.08 & 0.1 & 0.1 \\
\hline 内部摩擦角 (度) & 35 & 35 & 35 & 37 & 37 \\
\hline ダ 㧃㐴ンシ-角 (度) & 15 & 15 & 15 & 15 & 15 \\
\hline 間隙率 & 0.45 & 0.45 & 0.45 & 0.3 & 0.3 \\
\hline $\begin{array}{l}\text { 透水係数 } \\
(\mathrm{cm} / \mathrm{s})\end{array}$ & $\begin{array}{l}2.3 \mathrm{x} \\
10^{-1}\end{array}$ & $\begin{array}{l}2.3 \mathrm{x} \\
10^{-1}\end{array}$ & $\begin{array}{l}2.3 \mathrm{x} \\
10^{-1}\end{array}$ & $\begin{array}{l}5.6 \mathrm{x} \\
10^{-4}\end{array}$ & $\begin{array}{l}5.6 \mathrm{x} \\
10^{-4}\end{array}$ \\
\hline $\begin{array}{l}\text { Finn モデル } \\
\text { パラメータ }\end{array}$ & \multicolumn{5}{|c|}{$\begin{array}{ll}C_{1}=0.19, & C_{2}=1.00, \\
C_{3}=0.10, & C_{4}=0.50\end{array}$} \\
\hline
\end{tabular}




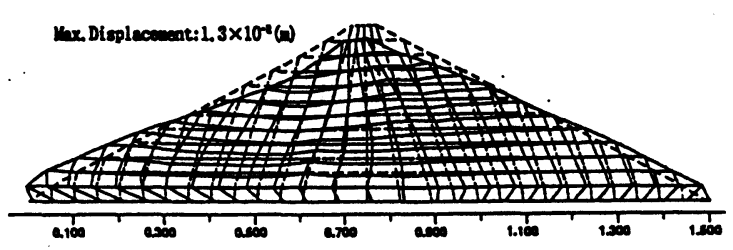

(U字谷模型中央断面, 箕面川波 $30 \mathrm{G}$ 加振時)

図-29 二次元弾塑性解析による残留変形の評価例
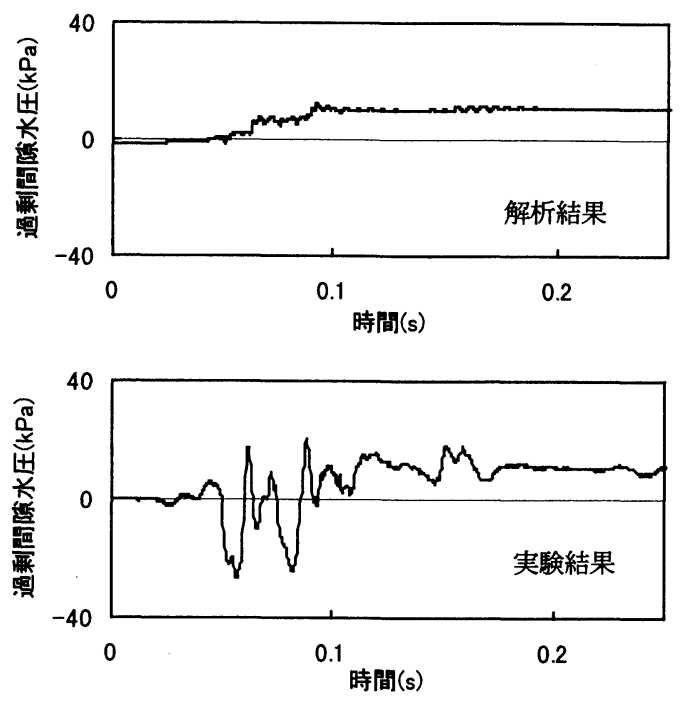

図-30 間隙水圧に関する解析と実験の比較 (箕面川波目標 $30 \mathrm{G}$ 加振)

\section{（2）過剩間隙水圧}

一例として, 図-30にP11点（図-4参照）の過剩 間隙水圧の時刻歴に関する解析と実験の比較結果を示 す. 解析では, 負の間隙水圧は算出されないことから 応答波の波形は実験結果と異なっている. しかし, 主 要動後の過剩間隙水圧は実験結果と同オーダーである. その值は, 初期有効拘束圧の 10～20\%程度であり，し かも, ロック部の深さが浅いほど過剩間隙水圧が小さ く, 地震時堤体の剛性に対する影響は小さいものと考 えられる.

\section{(3) 残留変形}

$\mathrm{U}$ 字谷模型の残留変形形状に関する解析結果の一例 を図ー29に示す. 解析により得られた堤体の残留変形 の特徵は, 天端付近のロックの沈下と, 上下流面の下 半部のはらみだしである.このような外形が実験の結 果と概ね一致しているが, 両者には本質的な差異があ る. これは, 模型実験と数值解析の変形メカニズムの 違いによるものであり, 模型実験では天端付近のロッ
ク粒子が振動により下方へ転落することで残留変形が 発生するのに対して, 二次元弾塑性解析では全体的な 塑性変形の結果として残留変形が発生している. ロッ クフィルダムの残留変形の評価に関しては, 簡便に残 留変形量を推定するための便宜的な方法と地震時の損 傷過程を正確に再現し得る精度の高い方法の両面から の取組みが必要であると考える.

\section{6. まとめ}

本研究で得られた主な結論は,つぎのとおりである.

(1) 大きなひずみレベルでの動的変形特性: 遠心載荷模 型振動実験に基づいて, 約 $5 \times 10^{-2}$ までのせん断ひ ずみに対する動的せん断剛性と隇衰定数の非線形 性を定量的に評価した.

(2) 地震時の加速度応答に及ぼす谷の影響: U字形とV 字形の 2 種類の谷形状を設定して比較検討した結 果, $\mathrm{V}$ 字谷模型よりもU字谷模型の方が地震時の加 速度応答および間隙水圧は大きくなった.これは, $\mathrm{V}$ 字谷模型の谷部の剛性が高く, 谷部の固有振動数 と加振波の卓越振動数と離れていることによるも のと考える.

(3) 残留変形と地震動レベルとの関連:残留変形が顕著 に出現し始めたのは，U字谷模型では箕面川波を $29.2 \mathrm{G}$ で加振した時, V字谷模型では箕面川波を $23 \mathrm{G}$ で加振した時であった. 実ダムに換算すれば, それぞれ $715 \mathrm{gal}$ と $560 \mathrm{gal}$ に匹敵するが，ダム底 部で概ね $500 \mathrm{gal}$ 程度までは残留変形は生じないも のと推察される.これは, 過去のロックフィルダム の地震被害事例とも概ね符合する.

(4) ロックフィルダムの損傷過程:ロックフィルダムの 損傷過程に関しては, ダム表層のロック部の粒形材 料が振動を受けて緩み, 強い振動を受けた際に上方 から下方へと転落する現象が主体である.こうした メカニズムの残留変形を解析評価する手法の開発 が必要である.

(5) 非常に強い地震動を受けた際の損傷形態: 非常に強 い地震動を受けた際のロックフィルダムの損傷形 態に関しては, ダム基礎で $1 \mathrm{G}$ 相当の地震動を作用 させた場合でも, 円弧すべりの破壊形態は生じなか った.これは, 粘着力がなく固結性の低いロック材 料においては, 地震動を受け場合に個々の材料の結 合が緩み, 地震動が大きくなるにつれて個々の材料 が非連続的な挙動をするようになることが理由で あると考察される.

(6) 地震時の間隙水圧 : 間隙水圧の時刻歴は, 加速度応 答波形と相似の形状を示し, 弾性体積変化により発 
生した水圧が主体を占めている. 模型底面で最大加 速度 $40 \mathrm{G}$ （実ダムでは $1 \mathrm{G}$ に相当）の地震動を作 用させた場合でも, ロック部の表層部では過剩間隙 水圧の残留は見られなかった. 深部では過剩間隙水 圧の残留が生じたが，過剩間隙水圧の残留分は, 最 大でも初期有効応力の 10〜20\%程度であった.こ の結果から, ロックフィルダムでは過剩間隙水圧に よる堤体材料剛性の低下は非常に小さいと考えら れる.

(7) 弾塑性解析による残留変形の評価に関する問題 点:遠心載荷振動実験により解明したロックフィル ダムの変形過程と弾塑性解析における変形メカニ ズムには本質的な差異があると考えられる, 弾塑性 解析により最終変形形態を予測したとしても, この 本質的な差異に注意することが必要である. 今後, 地震時の損傷過程を考慮した残留変形の評価手法 の精緻化が必要である.

\section{7. おわりに}

本研究では, ロックフィルダムの耐震性能を照査す る際に重要なポイントになる, 大きなひずみレベルで の動的変形特性, 地震時応答に及ぼす谷形状の影響, 非常に強い地震動を受けた際の残留変形, 損傷過程, 損傷形態, 地震時の間隙水圧の発生等について, 遠心 載荷模型振動実験によって明らかにし, 三次元動的解 析によって定量的な評価考察を加えた. 非常に強い地 震動に対してロックフィルダムは高い耐震性能を有し ていると考えられる.その耐震性能をより合理的に照 査するためには, 地震時に発生する残留変形を精度良 く評価すること, そして, 残留変形が発生した後の遮 水機能の保持を合理的に評価することが，今後の重要 な課題である.

謝辞 : 遠心載荷振動実験の実施に際しては, カリフォ ルニア大学デービス校 Bruce L. Kutter 教授，（株）大林 組技術研究所松田隆氏, 樋口俊一氏, 森拓雄氏に多大 なるご協力をいただきました. 記して深謝の意を表し ます.

\section{参考文献}

1) 有賀義明: 過去の実例に見るロックフィルダムの地震被 害と最大加速度との関係, 土木学会第 48 回年次学術講演 会講演概要集, I -83,pp.314-315, 1993

2) 田村重四郎:昭和 59 年長野県西部地震の震央域のダムの 挙動, 土木学会第 40 回年次学術講演会講演概要集, I -299, pp.597-598, 1985

3) 田村重四郎: メキシコ地震被害調查報告, 大ダム
No.116, pp.40-51,1986

4) 菊沢正裕: ロックフィルダムはなぜ地震に強いの か! , 水と土 No.70,pp.19-26, 1987

5) 三浦健志, 伊藤洋, 中村晋, 藤井義文: ロマプリエ夕地震 によるダムの被害, 土木学会第 45 回年次学術講演会講演 概要集, I -597-598,pp.1224-1227, 1990

6) 田村重四郎, 岡本舜三, 久保慶三郎, 龍岡文夫, 韓国城, 小川好, 野中昌明: 海城·唐山地震の被害と中国の而震研 究, 生産研究, Vol.34,No.1,pp.10-24, 1982

7) 安田正幸: フィルダムの耐震設計の動向, 発電水力, No.144, pp.52-59, 1976

8) Kutzner, C.: Design and Construction of Earthquake-Resistant Earth and Rock-fill Dams,Geo-technical Engineering, Vol.16, pp.1-25, 1985

9) Romo, M.P., Raserdig, D. : Computed and Observed Deformation of two Embankment Dams under Seismic Loading, Dams and Earthquake,pp.267-274, 1981

10) Stroppini, E.W. : The Oroville Earthquake and Oroville Dam, Eng. Found. Conf.Eval.Dam Safety, pp.301-328, 1977

11) Housner, G.W., Scott, R.F. : Earthquake Consideration in Dam Design, Water Power \& Dam Construction Vol.31, No.7, pp.31-37, 1979

12) Okamoto, S. : Introduction to Earthquake Engineering ( $2^{\text {nd }}$ Edition), University of Tokyo, 1984

13) 田村重四郎, 岡本舜三, 加藤勝行, 大町達夫: ロックフィ ルダムの模型の振動破壊実験による動的破壊機構の研究, 第 4 回日本地震工学シンポジウム論文集, pp.703-710, 1975

14)田村重四郎, 韓国城, 加藤勝行: フィルダム砂模型の 振動破壊機構に関する研究一特に粘着力の影響について, 第 6 回日本地震工学シンポジウム論文集, No.116, pp.921927, 1982

15) 渡辺啓行: 模型振動実験からみたフィルダムの動特性, 土 と基礎，Vol.28,No.5(268), pp.25-32, 1980

16) 長谷川高士, 㐘沢正裕: 振動台模型実験におけるフィルダ ムの動的挙動, 農業土木学会論文集, No.95, pp.57-64, 1981

17) 大根義男, 建部英博, 成田国朝, 奥村哲夫: フィルダムの 耐震設計に関する基礎的研究, 土木学会論文集, No.339, pp.127-136, 1983

18) 渡辺啓行, 五月女敦:模型土質斜面の傾斜破壊実験と数値 解, 土木学会論文集, No.376/III-6, pp.31-40, 1986

19) Zienkiewicz, O.C., Chang, C.T., Bettess, P.:Drained, undrained, consolidation and dynamic behavior assumptions in soils, Geotechnique, Vol.30, No.4, pp.385-395, 1980

20)津国正一, 岩下友也, 館野悟, 中村昭: 初期せ九断応力が作 用する密な疎粒材料の動的強度特性, 第 31 回地盤工学研 究発表会発表講演集, No.539,pp.1077-1078, 1996

21) 松本徳久, 安田成夫, 芳方良一: ロック材料の三軸試験お 
よびねじり単純せん断試験による非排水動的挙動, 土木 学会論文集, No.554,pp.173-184, 1996

22)岩下友也, 館野悟, 吉田等, 津国正一:粗粒材料の動的せん 断強度とダイレータンシー特性の関係, 第 24 回地震工学 研究発表会講演論文集, B8-6, pp.529-532, 1997

23) 平田和太: フィルダムの動的解析における地下逸散減衰 の評価, 電力中央研究所我孫子研究所報告, No.U88061, 1989

24) 松本徳久, 安田成夫, 豊田光雄, 志賀三智:三保ダムにおけ る実地震記録の解析, 土木技術資料, Vol.26, No.7, pp.915,1984

25) 藤沢㑆彦, 永山功, 吉田等, 佐々木隆, 岩下友也: 地震時に おけるダムの安全性に関する検討, 土木技術資料, Vol.39, No.3, pp.26-31, 1997

26) 松本徳久, 成田成夫:ロックフィルダムの動的解析におけ る入力物性値と非線形解析, ダム技術, Vol.3, No.4, pp.1530, 1985

27) 渡辺啓行: フィルダムの動的解析- I -動的解析の方法-, 大ダム, No.87, pp.46-64, 1979

28)大町達夫: ロックフィルダムが地震に強いのはなぜか, 電 力土木, No.223, pp.3-13, 1989

29) 建設省土木研究所 : フィルダム堤体の三次元的地震時挙 動特性に関する検討報告書, 土木研究所資料, ISSNO386-5878, 資料, No.2356,pp.1-148, 1986

30) Dakoulas, P., Gazetas, G. : Seismic Shear Vibration of Embankment Dams in Semi-cylindrical Valleys, Earthquake Engineering and Structural Dynamics, Vol.14, No.1, pp.19-40, 1986

31) Gazetas, G., Dakoulas, P. : Seismic Analysis and Design of Rock-fill Dams State-of-the-art, Soil Dynamics and Earthquake Engineering, No.11, pp.27-61, 1992
32) 岩下友也, 井根健, 吉田等 : フィルダムの堤敷における 地震時動的相互作用と堤敷観測波からの基盤入射波の推 定, ダム工学, Vol.8, No.4, pp.270-282, 1998

33) 石原研而 : 土質動力学の基礎, 鹿島出版会, pp.238-240, 1982

34) 電源開発株式会社 : “UNIVERSE” A Program for the 3-D Static \& Dynamic Analysis of Dams, 1999

35) Hiroyuki Watanabe, Zengyan Cao, Kenji Kikuchi : Dynamic Behavior of A Rock-fill Dam and It's Material Properties, $19^{\text {th }}$ ICOLD, Q73.R40, pp.673-693, 1997

36) Watanabe, H., Cao, Z.: Upstream Boundary of Reservoir In Dynamic Analysis, Journal of Engineering Mechanics, ACSE. Vol.124,pp.468-470, 1998

37) 有賀義明, 渡辺啓行, 吉田昌稔, 曹増延 : 三次元夕゙ム基礎一貯水池連成系における逸散減衰に関する一考察, 第 10 回日本地震工学シンポジウム論文集, E4-18, pp.2021-2026, 1998

38)有賀義明: ロックフィルダムの地震時応答特性に関する 遠心載荷振動実験, 土木学会第 25 回地震工学研究発表会 講演論文集, B8-6, pp.445-448, 1999

39）有賀義明,曹増延:遠心載荷振動実験によるロックフィル ダムの地震時損傷に関する検討,第 1 回構造物の破壊過程 解明に基づく地震防災性向上に関するシンポジウム論文 集,e-12,pp.259-262,2000

40) 三浦房紀，沖中宏志：仮想仕事の原理に基づく粘性境界 を用いた三次元構造物一地盤系の動的解析手法, 土木学 会論文集, No.404/I-11, pp.395-404, 1989

\title{
STUDY ON SEISMIC STABILITY OF ROCK-FILL DAM DURING STRONG ERATHQUAKES BY MEANS OF DYNAMIC CENTRIFUGE TEST AND 3-D DYNAMIC ANALYSIS
}

(2001.11.13 受付)

\author{
Yoshiaki ARIGA, Zengyan CAO and Hiroyuki WATANABE
}

\begin{abstract}
A centrifugal dynamic experiment and relevant numerical analyses have been carried out for assessing the seismic stability of a rockfill dam against strong earthquakes. The central core dam model was $40 \mathrm{~cm}$ in height and both the upstream and downstream slopes were 1:1.8. A reservoir $32 \mathrm{~cm}$ deep was coupled with the dam and the valley was alternatively modelled in a $\mathrm{U}$ shape or a V shape. The whole model was set at a gravity field $40 \mathrm{G}$ and shaken by various waves of the maximum acceleration 40G. Numerical simulations were performed for interpreting the experiment. Such work has resulted in an understanding of the seismic stability of the rockfill dam. The dynamic properties of the dam materials in large strain status have been quantitatively evaluated. The behaviors of excessive pore water pressure in rock zone have been examined. The damage process and the failure mode have been understood primarily.
\end{abstract}

